\title{
The out-of-pocket burden of chronic diseases: the cases of Belgian, Czech and German older adults
}

\author{
Veronika Kočiš Krůtilová ${ }^{*}\left(\mathbb{D}\right.$, Lewe Bahnsen² and Diana De Graeve ${ }^{3}$ (D)
}

\begin{abstract}
Background: Out-of-pocket payments have a diverse impact on the burden of those with a higher morbidity or the chronically ill. As the prevalence of chronic diseases increases with age, older adults are a vulnerable group. The paper aims to evaluate the impact of chronic diseases on the out-of-pocket payments burden of the 50+ populations in Belgium, the Czech Republic and Germany.

Methods: Data from the sixth wave of the Survey of Health, Ageing and Retirement in Europe is used. A two-part model with a logit model in the first part and a generalised linear model in the second part is applied.

Results: The diseases increasing the burden in the observed countries are heart attacks, high blood pressure, cancer, emotional disorders, rheumatoid arthritis and osteoarthritis. Reflecting country differences Parkinson's disease and its drug burden is relevant in Belgium, the drugs burden related to heart attack and outpatient care burden to chronic kidney disease in the Czech Republic and the outpatient care burden of cancer and chronic lung disease in Germany. In addition, we confirm the regressive character of out-of-pocket payments.
\end{abstract}

Conclusions: We conclude that the burden is not equitably distributed among older adults with chronic diseases. Identification of chronic diseases with a high burden can serve as a supplementary protective feature.

Keywords: Out-of-pocket burden, Chronic diseases, Older adults, Belgium, Czech Republic, Germany

\section{Background}

Chronic diseases are estimated to cause nearly $90 \%$ of all deaths and count for $87 \%$ of all lost healthy life years in the European Union (EU) [1]. Chronic diseases impose a considerable burden on individuals and households and have not only health-related and social implications but also economic implications [2,3]. Economic implications mostly arise from the fact that even if health care access is mostly universal, and coverage is extensive in Europe, some health care goods and services must be paid out-ofpocket. Due to legal regulations, out-of-pocket payments

\footnotetext{
* Correspondence: veronika.krutilova@mendelu.cz

${ }^{1}$ Faculty of Business and Economics, Mendel University in Brno, Zemedelska 1, 61300 Brno, Czech Republic

Full list of author information is available at the end of the article
}

(OOPP) for health care goods and services remain and appear either in the form of cost sharing or direct payments. Those individuals who exhibit a higher morbidity are thus more likely to be confronted with OOPP. Furthermore, if no legal exemptions from OOPP are applied, the chronically ill in particular face a higher financial burden of their budgets due to permanent and increased health care consumption [4]. In addition, the presence of chronic diseases not only influences an individual's labour market participation and productivity resulting in lower earnings but could also lead to disability, early retirement or other types of dependence on social security systems $[2,5]$. These factors further constrain household budgets and significantly increase the financial burden for those with chronic conditions compared to the general population [6]. 
As the prevalence of chronic diseases increases with age [7] and increasing age is an important predictor of multimorbidity $[8,9]$, the burden from chronic diseases is especially high among older adults [6]. The combination of economic inactivity, resulting in lower disposable income and increased morbidity, leads to a higher share of their budget being spent on health-related OOPP $[10,11]$. As a direct consequence, older adults are the most vulnerable group affected by the OOPP burden [12-14] and forgone health care [15, 16].

Our paper contributes to the discussion about the OOPP burden of older adults and extends it by the dimension of health-related aspects. Based on the fact that the relationship between chronic diseases and OOPP has been shown $[9,10,19]$ the objective of the paper is to evaluate the impact of specific chronic diseases on the OOPP burden of older adults. The OOPP burden is defined as a share of net equivalised income spent on OOPP. To provide a comprehensive understanding of this issue in complex health care systems we analyse the situation in Belgium, the Czech Republic and Germany where despite well-developed health care systems with extensive packages of health care services covered and various protective measures against high OOPP implemented, older people still report difficulties to afford payments for health care [31, 47, 48]. We aim to answer the following research questions: Does the OOPP burden of older adults differ according to chronic diseases they have? Does the impact of chronic diseases on the OOPP burden differ between certain types of OOPP -namely drug, outpatient and inpatient care payments? The identification of these points is crucial for policy makers in order to understand the relevance of chronic diseases for cost sharing policies and to target more efficiently protection of the most vulnerable.

The OOPP burden for older adults including the aspect of various chronic diseases has already been studied for the USA $[9,17,18]$ and Australia [19]. However, to the best of our knowledge, studies of the burden of older adults and the association with particular chronic health conditions are rare in Europe. We are only aware of the study by Arsenijevic et al. [10] which includes some European countries, however, they explore a different range of OOPP (including home/nursing care) and for a limited set of chronic diseases. The concept of their study was also different because they focused only on catastrophic payments (OOPP exceeding 10\% of income). We believe that our study provides important insights into the burden of OOPP of older adults and associated factors, especially chronic diseases.

The paper is organised as follows: firstly, health care systems in Belgium, the Czech Republic and Germany and their coverage and OOPP are briefly introduced; secondly, data and methods used are described; in the third part we present our results which are further discussed in the following part of the paper; and finally we summarise our main findings.

\section{Health care coverage and out-of-pocket payments}

Belgium, the Czech Republic and Germany have welldeveloped social health insurance systems covering an extensive package of services - including inpatient and outpatient care and drugs [20-22]. Uninsured services are mainly restricted to non-essential drugs such as drugs for diarrhoea or stomach pain or homeopathic drugs, and treatment or surgery at the patient's request (e.g. plastic surgery or cosmetic interventions). Social insurance is compulsory, except in Germany where the self-employed and employees above an income threshold are free to opt for private health insurance instead - which is effectively done by about $10 \%$ of the population. ${ }^{1}$ Supplementary insurance is a common part of the health care system in Belgium and Germany. In the Czech Republic, there is practically no supplementary insurance and voluntary insurance plays a marginal role (mostly used for travel health insurance, cosmetic surgery). The level of OOPP, expressed as a share of total health expenditure, differs from $13 \%$ in Germany to $15 \%$ in the Czech Republic and $18 \%$ in Belgium [23].

OOPP appear as co-payments, co-insurance and direct payments. All three countries secure a certain financial protection from high OOPP and exemptions from payments are applied for specific vulnerable groups (partial or full). OOPP are briefly described for each country and an overview of OOPP settings is presented in Table 1.

\section{Belgium}

The share of co-payments in total OOPP amounts to about 15 to $17 \%$ [22] with relatively large differences according to the specific service and circumstances. For example, beneficiaries pay about $€ 4$ to $€ 6$ and $€ 13$ to $€ 14$ for a general practitioner (GP) consultation and home visit respectively and $€ 7$ to $€ 12$ for a specialist consultation. There is a mix of fixed and variable direct payments for hospitalisation. For reimbursed drugs, co-insurance varies between 0 and $80 \%$ of the price according to the type of drug.

Supplementary payments (where a physician/health care facility is allowed to charge a price that is higher than the conventional/agreed tariff) are quite common in Belgium for outpatient care and especially for inpatient care in one-person bedrooms. Additional payments in one-person bedrooms can be quite large - up to $€ 1237$ on average in 2015 [24].

Regarding financial protection, an annual limit of total OOPP, excluding supplementary payments and uninsured services, is in place at the household level. The

${ }^{1}$ Specific regulations of private health insurance in Germany will be left out of consideration. 
Table 1 Overview of OOPP settings and protection measures

\begin{tabular}{|c|c|c|c|c|c|c|}
\hline Country & $\begin{array}{l}\text { Type of } \\
\text { Care }\end{array}$ & Co-payment & Co-insurance & $\begin{array}{l}\text { Supplementary } \\
\text { payments }\end{array}$ & $\begin{array}{l}\text { Uninsured } \\
\text { services }\end{array}$ & Protection measures \\
\hline \multirow[t]{3}{*}{ Belgium } & Outpatient & NA & $\begin{array}{l}\text { GP and specialist } \\
\text { consultations, GP home } \\
\text { visits, physiotherapy, } \\
\text { speech therapy, } \\
\text { podology, etc. }\end{array}$ & $\begin{array}{l}\text { Non-convention } \\
\text { healthcare } \\
\text { providers }\end{array}$ & $\begin{array}{l}\text { Individual } \\
\text { health services }\end{array}$ & \multirow{3}{*}{$\begin{array}{l}\text { Household level annual maximum for } \\
\text { co-payments and co-insurance from } \\
450 \text { to } 1800 \text { EUR according to income. } \\
\text { A maximum for the chronically ill re- } \\
\text { duced by } 100 \text { EUR. Lower co-payments } \\
\text { and co-insurance for low-income } \\
\text { households. }\end{array}$} \\
\hline & Drugs & NA & $\begin{array}{l}\text { Various } \% \text { according to } \\
\text { drug category }\end{array}$ & NA & $\begin{array}{l}\text { Non-essential } \\
\text { drugs (e.g. } \\
\text { diarrhoea, } \\
\text { stomach pain) }\end{array}$ & \\
\hline & Inpatient & $\begin{array}{l}\text { Flat rate charge per } \\
\text { day for inpatient } \\
\text { stay, drugs; per stay } \\
\text { for tests, radiology }\end{array}$ & A & $\begin{array}{l}\text { A (e.g. one- } \\
\text { person rooms) }\end{array}$ & $\begin{array}{l}\text { Individual } \\
\text { health services }\end{array}$ & \\
\hline \multirow[t]{3}{*}{$\begin{array}{l}\text { Czech } \\
\text { Republic }\end{array}$} & Outpatient & $\begin{array}{l}\text { Emergency visit fee } \\
3.5 \text { EUR; flat rate } \\
\text { charge for } \\
\text { therapeutic aids }\end{array}$ & NA & NA & $\begin{array}{l}\text { Individual } \\
\text { health services }\end{array}$ & $\begin{array}{l}\text { Exemptions from emergency visit fee } \\
\text { for defined vulnerable groups }\end{array}$ \\
\hline & Drugs & $\begin{array}{l}\text { Flat rate charge per } \\
\text { package }\end{array}$ & NA & NA & $\begin{array}{l}\text { Non-essential } \\
\text { drugs (e.g. } \\
\text { diarrhoea, cold, } \\
\text { pain); } \\
\text { contraception }\end{array}$ & $\begin{array}{l}\text { Individual annual maximum for drug } \\
\text { co-payments: basic ( } 200 \text { EUR); lowered } \\
\text { for younger } 18 \text { and older } 65 \text { (100 EUR) }\end{array}$ \\
\hline & Inpatient & NA & NA & $\begin{array}{l}\text { Above standard } \\
\text { services (one- } \\
\text { person rooms) }\end{array}$ & $\begin{array}{l}\text { Individual } \\
\text { health services }\end{array}$ & NA \\
\hline \multirow[t]{3}{*}{ Germany } & Outpatient & $\begin{array}{l}\text { Physiotherapy } 10 \\
\text { EUR per day }\end{array}$ & $\begin{array}{l}10 \% \text { (min. } 5 \text { EUR and } \\
\text { max. } 10 \text { EUR) for } \\
\text { transport services, } \\
\text { therapeutic aids }\end{array}$ & NA & $\begin{array}{l}\text { Individual } \\
\text { health services }\end{array}$ & $\begin{array}{l}\text { Individual annual maximum for co- } \\
\text { payments: } 2 \% \text { of household gross in- } \\
\text { come; } 1 \% \text { for chronically ill }\end{array}$ \\
\hline & Drugs & NA & $\begin{array}{l}10 \% \text { for prescription } \\
\text { drugs (min. } 5 \text { EUR and } \\
\text { max. } 10 \text { EUR); } 10 \% \text { for } \\
\text { herbal remedies }\end{array}$ & NA & $\begin{array}{l}\text { Non-essential } \\
\text { drugs (e.g. } \\
\text { diarrhoea, } \\
\text { stomach pain) }\end{array}$ & \\
\hline & Inpatient & $\begin{array}{l}\text { Flat rate charge } 10 \\
\text { EUR per day for a } \\
\text { maximum of } 28 \text { day } \\
\text { per year }\end{array}$ & NA & $\begin{array}{l}\text { Above standard } \\
\text { services (one- } \\
\text { person rooms) }\end{array}$ & $\begin{array}{l}\text { Individual } \\
\text { health services }\end{array}$ & \\
\hline
\end{tabular}

$A$ applicable, GP general practitioner, NA not applicable

maximum limit varies between $€ 450$ and $€ 1800$ according to income (e.g. a net taxable household income up to $€ 17,780$ is considered for a limit of $€ 450$; an income above $€ 46,042$ for a limit of $€ 1800$ (figures for 2015)). Low-income households pay lower co-payments and coinsurance and are better protected against supplementary payments. Furthermore, people with chronic illness (defined as having more than $€ 300$ health insurance expenditures during eight consecutive quarters constituting two calendar years) are entitled to a third-party payment scheme for physicians and dentists and a reduction of $€ 100$ of their maximum payment ceiling. Other benefits are conditional, e.g. individuals can also receive an allowance varying between $€ 300$ and $€ 600$ if they have paid at least $€ 450$ co-payments over two consecutive years and were hospitalised more than six times or more than 120 days in a year, received specific nursing care, etc.

\section{Czech Republic}

More than half of all OOPP is paid for drugs either in the form of direct payments for over-the-counter (OTC) pharmaceuticals or co-payments for prescribed drugs. Co-payments for prescribed drugs are set as flat charges based on a drug category reflecting a difference between a price of the drug in pharmacies and a set reimbursement from health insurance. In outpatient care, OOPP are applied for medical aids (mostly co-payments) and an emergency unit visit fee of $€ 3.5$. It is claimed that there might be some forms of informal payments for inpatient care, however, there are no estimates of the real magnitude [20]. Typical direct payments in inpatient care are payments for one-person bedrooms.

Regarding financial protection, an individual annual maximum (only) for drug co-payments of $€ 200$ is in place. The annual limit is reduced to $€ 100$ for individuals aged 18 years or younger and 65 years or older (the 
state in 2015). However, a full co-payment for medication is not always included in the limit. The amount of co-payment included within the limit corresponds to the co-payment of the cheapest available drug with the same treatment substance and means of application. In addition, provided that the given drug is in the group of therapeutically interchangeable drugs (the same drug fully reimbursed from health insurance is available) the co-payment is not included in the protective limit at all. Specific vulnerable groups - such as individuals below subsistence income level, children in foster homes or orphanages, or older adults in nursing homes with limited income - are fully exempted only from the emergency unit visit fee. There are no other special exemptions in the health care system.

\section{Germany}

Statutorily insured persons are obliged to pay copayments and co-insurance for health services and drugs reimbursed from statutory health insurance. In principle, for drugs, therapeutic aids and travel expenses insured persons pay $10 \%$ of the costs, but at least $€ 5$ and no more than $€ 10$. However, co-payments will never exceed the total cost. There are special regulations for herbal remedies, ambulant home care and physiotherapy. For remedies, it is a co-insurance of $10 \%$ of the selling price. Physiotherapy (either outpatient or inpatient) requires $€ 10$ per day. In inpatient care, people have to pay $€ 10$ per day for a maximum of 28 days. Regarding financial protection, each insured person must pay OOPP only up to his or her individual limit per calendar year. This burden limit accounts for $2 \%$ of the family gross income. A lower burden limit of $1 \%$ applies for the chronically ill. Further, for insured persons receiving social assistance the burden limit relates to the received social allowance. If these maximum limits are reached, people are exempted from further co-payments and co-insurance within the respective year. However, the application of the burden limit is not automatic and is based on request. A compact overview of the German OOPP regulations can be found elsewhere [21,25].

\section{Methods}

\section{Data source and variables used}

For our analysis we use the sixth wave of the Survey of Health, Ageing and Retirement in Europe (SHARE) conducted in 2015 [26]. SHARE is a multidisciplinary panel database of cross-national micro data containing detailed information from the areas of economics, health, and psychology as well as social and family networks [27]. In that regard, it covers the population aged 50 years and older of most European countries and Israel. Malter and Börsch-Supan [28] document questionnaire innovations, methodological improvements, new procedures and other important changes introduced during the sixth wave. Our target population are the non-institutionalised individuals aged 50 and older from Belgium, the Czech Republic and Germany.

\section{Dependent variable(s)}

In the used data, OOPP are defined as payments made directly to health care providers without any reimbursement from a third party and co-payments (co-insurance) for services partly paid by a third party. We adopt a relative definition of the OOPP burden in our study which stems from the WHO's concept of fairness in financial contributions for health care and households' capacity to pay for health care $[29,30]$. We refer to a household's net income as the capacity to pay, which is commonly used for studies focusing on the OOPP burden [10, 11, 19, 31, 32]. The dependent variable, the OOPP burden, is defined as the share of OOPP in equivalised net income. Due to economies of scale in consumption using equalised income allows us to account for differences in household size. We construct the equivalised income by applying the square root scale as a more recent method used by OECD [33]. In addition to looking at the total OOPP burden, we use the burden of the respective OOPP types: payments for drugs (prescribed drugs and OTC pharmaceuticals), outpatient care (contacts with medical doctors, qualified nurses, therapists, emergency rooms, outpatient clinic visits, including expenses for diagnostic examinations, excluding dentist visits) and inpatient care (stays in hospitals and other health care facilities) as dependent variables to gain further insights. Table 2 shows the distribution of OOPP burdens in respective countries for respective OOPP types.

\section{Independent variables}

As OOPP appear at the point of use, the investigation of the burden closely relates to health care consumption and its patterns. Therefore, the primary set of independent variables for our analysis rests on the "Andersen model" for the utilisation of health care services [34]. This approach classifies three categories of individual determinants influencing health care utilisation, namely predisposing, need and enabling factors. Predisposing factors exist prior to the presence of a certain illness and include the consumer's predictable characteristics such as age, gender, marital status, previous health behaviour, race or ethnicity, family size and its composition, religion, and region of the country and residence. These factors are extended by the beliefs health care consumers have (values concerning health, knowledge about disease and treatment, and attitudes towards health care services). Need factors represent the most urgent reason to utilise health care as they relate to the onset of illness. They distinguish subjective need (self-perceived health 
Table 2 Distribution of OOPP burden in 2015 (in Euro/in \% of equivalent income) (wave 6)

\begin{tabular}{lllll}
\hline Country & Total OOPP & Drugs & Outpatient care & Inpatient care \\
\hline Belgium & $440.54 / 2.19$ & $235.35 / 1.19$ & $166.15 / 0.78$ & $39.03 / 0.20$ \\
& $(536.34 / 3.13)$ & $(313.30 / 1.87)$ & $(310.86 / 1.63)$ & $(209.90 / 1.25)$ \\
Czech Republic & $113.51 / 1.76$ & $72.14 / 1.14$ & $37.17 / 0.55$ & $4.19 / 0.06$ \\
& $(132.63 / 2.25)$ & $(81.84 / 1.46)$ & $(93.76 / 1.52)$ & $(33.13 / 0.51)$ \\
Germany & $299.34 / 1.44$ & $92.48 / 0.48$ & $183.83 / 0.83$ & $23.54 / 0.12$ \\
& $(521.20 / 2.70)$ & $(121.74 / 0.72)$ & $(476.84 / 2.40)$ & $(94.23 / 0.55)$ \\
\hline
\end{tabular}

Note: average burden expressed in the absolute term in Euro/average burden expressed in the relative term in \% of equivalent income; standard deviation in parentheses

status, symptoms of illness and disability) and objectively recognised need (physician-rated urgency of present condition, stated diagnoses, symptoms, etc.). Enabling factors ensure the possibility of access to health care. Factors such as several sources of income, education, insurance coverage, the regular source of care and the price of health services are considered.

The selected variables for our analyses are further benchmarked with those used in previous studies focusing on the OOPP burden [10, 11, 19, 31, 32, 35]. The final set of selected variables is based on results of multicollinearity and goodness-of-fit tests (see section Methodology).

The need factors are of main importance. We incorporate health-related variables which are of a subjective as well as objective nature. To answer our research questions, we include 15 diagnosed health conditions as dummy variables and a group having other conditions for a complete picture. In our study, we use the term "chronic diseases" for the observed health conditions which are in accordance with perception of chronic diseases in a broader term [36]. Table 3 presents these diseases in a more detail.

Further, limitations in basic activities (ADL; dressing, eating, walking, hygiene and using the toilet) and in instrumental activities of daily living (IADL; shopping, housekeeping, accounting, food preparation and taking medication) enter the model. Both are dummy variables, taking the value 1 if limitations exist. Finally, we control for predisposing (socio-demographic characteristics) and enabling (economic) factors. Socio-demographic variables observed are gender, age (recoding into three categories: 50 to 64,65 to 79 and $80+$ ) and marital status (distinguishing four states: living in cohabitation, separated, never married, widowed). The enabling factors included are education (measured according to the International Standard Classification of Education ISCED-97 but recoded into three categories; having none/primary education, secondary and tertiary education) and income (income distribution expressed as equalised income quartiles). Lastly, we include a variable for supplementary health insurance related to institutional settings of the observed health care systems.
Table 4 displays sample characteristics of respective variables for the three countries.

\section{Methodology}

As the dependent variable belongs to the class of limited dependent variables features such as zero mass, nonnegativity, right-skewness and heavy tails make more sophisticated handling necessary. ${ }^{2}$ In order to deal with these issues, the literature provides a variety of different approaches [37, 38]. The most straightforward approach which is well-suited to modelling individual health care consumption and burden and is able to deal with the mentioned features is the two-part model (2 PM) [3941]. An alternative approach is the sample selection model (SSM) [42]. However, a long debate about how to model health expenditures with zero mass leaves us with the suggestion to compare both methods and the model performance [43]. Following this, we ran our models using both methods, then compared model diagnostics and further checked the condition index and combined it with a z-test. Based on this we choose the $2 \mathrm{PM}$ over the SSM.

The 2 PM assumes a sequential decision and decomposes OOPP made into two random components and models each separately. This leads to predictions for the first part -- the probability of having any OOPP -- and for the second part -- the expected burden of OOPP conditional upon having any OOPP. With these two values, we are able to predict the mean share of OOPP in income, conditional on the included independent variables. The first part -- the probability of observing positive OOPP versus zero expenses -- we estimate by means of a logit model. Conditional on having positive OOPP, we then estimate a generalised linear model (GLM) for the second part. Another common option for the second part is to use OLS on the log-transformed dependent variable. However, GLM has the advantage that it eases the homoscedasticity and normality

\footnotetext{
${ }^{2}$ The share of zeros, indicating having no OOPP, is $4.60 \%$ (Belgium), 7.13\% (Czech Republic) and 14.93\% (Germany). Values for skewness and kurtosis indicate a highly right-skewed distribution with very heavy tails.
} 
Table 3 Description of observed chronic diseases

\begin{tabular}{|c|c|}
\hline \multicolumn{2}{|l|}{ Chronic diseases } \\
\hline Heart attack & $\begin{array}{l}\text { Heart attack including myocardial infarction, coronary } \\
\text { thrombosis or any other heart problem including } \\
\text { congestive heart failure }\end{array}$ \\
\hline $\begin{array}{l}\text { High blood } \\
\text { pressure }\end{array}$ & High blood pressure or hypertension \\
\hline $\begin{array}{l}\text { High blood } \\
\text { cholesterol }\end{array}$ & High blood cholesterol \\
\hline Stroke & Stroke or cerebral vascular disease \\
\hline Diabetes & Diabetes or high blood sugar \\
\hline Lung disease & $\begin{array}{l}\text { Chronic lung disease such as chronic bronchitis or } \\
\text { emphysema }\end{array}$ \\
\hline Cancer & $\begin{array}{l}\text { Cancer or malignant tumour, including leukaemia or } \\
\text { lymphoma, but excluding minor skin cancers }\end{array}$ \\
\hline Ulcer & Stomach or duodenal ulcer, peptic ulcer \\
\hline Parkinson & Parkinson's disease \\
\hline Cataracts & Cataracts \\
\hline Alzheimer & $\begin{array}{l}\text { Alzheimer's disease, dementia, organic brain } \\
\text { syndrome, senility or any other serious memory } \\
\text { impairment }\end{array}$ \\
\hline $\begin{array}{l}\text { Emotional } \\
\text { disorders }\end{array}$ & $\begin{array}{l}\text { Other affective or emotional disorders, including } \\
\text { anxiety, nervous or psychiatric problems }\end{array}$ \\
\hline $\begin{array}{l}\text { Rheumatoid } \\
\text { arthritis }\end{array}$ & Rheumatoid arthritis \\
\hline Osteoarthritis & Osteoarthritis, or other rheumatism \\
\hline $\begin{array}{l}\text { Chronic kidney } \\
\text { disease }\end{array}$ & Chronic kidney disease \\
\hline Other conditions & $\begin{array}{l}\text { Other not mentioned chronic conditions and other } \\
\text { non-chronic conditions (e.g. fractures) }\end{array}$ \\
\hline
\end{tabular}

Note: Descriptions are taken from the SHARE main questionnaire for the sixth wave from the variable PH006_DocCond: Has a doctor ever told you that you had/ Do you currently have any of the conditions on this card? (With this we mean that a doctor has told you that you have this condition, and that you are either currently being treated for or bothered by this condition)

assumptions and weakens bias due to retransforming to the original scale. GLM makes it necessary to specify on the one hand a family that reflects the mean-variance relationship, and on the other hand a link function which provides the relationship between the linear predictor and the mean of the distribution function. To identify the correct family and link, we apply several tests, namely the modified Park test, the Pregibon link test, the Pearson correlation test and the modified HosmerLemeshow test. Additionally, Akaike and Bayesian information criteria, log-likelihood and deviance values are used. Diagnostics yield a gamma distribution with a power link of 0.2 for Belgium, a Poisson distribution with a power link of 0.5 for the Czech Republic and a gamma distribution with a power link of 0.5 for Germany.

We ran four regression models (a main model for total OOPP burden, models for drugs, outpatient and inpatient care burden) for each country separately with
Table 4 Sample characteristics (percentage shares)

\begin{tabular}{|c|c|c|c|}
\hline Variables & Belgium & Czech Republic & Germany \\
\hline \multicolumn{4}{|l|}{ Gender } \\
\hline - female & 54.92 & 59.42 & 52.46 \\
\hline - male & 45.08 & 40.58 & 47.54 \\
\hline \multicolumn{4}{|l|}{ Age } \\
\hline$\cdot 50-64$ & 48.17 & 35.84 & 45.73 \\
\hline • 65-79 & 38.45 & 51.90 & 44.01 \\
\hline$\cdot 80+$ & 13.38 & 12.25 & 10.26 \\
\hline \multicolumn{4}{|l|}{ Marital status } \\
\hline - cohabitation & 66.82 & 63.80 & 73.98 \\
\hline • seperated & 14.09 & 14.05 & 9.87 \\
\hline • never married & 5.98 & 2.16 & 4.92 \\
\hline - widowed & 13.12 & 20.00 & 11.23 \\
\hline \multicolumn{4}{|l|}{ Education } \\
\hline • none/primary & 37.60 & 38.32 & 11.54 \\
\hline - secondary & 27.36 & 47.82 & 57.15 \\
\hline - tertiary & 35.03 & 13.86 & 31.31 \\
\hline \multicolumn{4}{|l|}{ Income } \\
\hline - 1st quartile & 25.00 & 25.00 & 25.00 \\
\hline -2nd quartile & 25.00 & 25.00 & 25.00 \\
\hline - 3rd quartile & 25.00 & 25.00 & 25.00 \\
\hline - 4th quartile & 25.00 & 25.00 & 25.00 \\
\hline Heart attack & 9.34 & 12.65 & 10.31 \\
\hline High blood pressure & 34.01 & 52.29 & 42.41 \\
\hline High blood cholesterol & 30.36 & 25.35 & 18.20 \\
\hline Stroke & 3.38 & 4.23 & 3.51 \\
\hline Diabetes & 11.25 & 19.85 & 14.07 \\
\hline Lung disease & 7.06 & 7.60 & 8.01 \\
\hline Cancer & 5.05 & 4.74 & 6.10 \\
\hline Ulcer & 5.66 & 3.96 & 2.07 \\
\hline Parkinson & 0.72 & 1.04 & 0.86 \\
\hline Cataracts & 7.22 & 10.05 & 8.75 \\
\hline Alzheimer & 1.29 & 1.95 & 1.60 \\
\hline Emotional disorders & 8.08 & 5.14 & 7.71 \\
\hline Rheumatoid arthritis & 6.63 & 10.66 & 11.95 \\
\hline Osteoarthritis & 32.16 & 28.61 & 21.61 \\
\hline Chronic kidney disease & 1.60 & 2.50 & 2.11 \\
\hline Other conditions & 16.74 & 18.60 & 18.59 \\
\hline $\mathrm{ADL}$ & 14.64 & 13.20 & 10.47 \\
\hline IADL & 21.25 & 20.48 & 14.00 \\
\hline Supplementary health insurance & 81.67 & 6.07 & 29.18 \\
\hline N & 5566 & 4726 & 4308 \\
\hline
\end{tabular}


these specifications in order to distinguish countryspecific differences within the observed period. We report the results of the $2 \mathrm{PM}$ as average marginal effects (AMEs) which show the incremental effects for the complete 2 PM (logit and GLM combined). The results for the sensitivity analysis of the main model can be found in the supplementary files.

\section{Results}

\section{Factors affecting the OOPP burden}

Presenting results, we first focus on the factors affecting the total OOPP burden (Table 5) and then briefly describe and compare it with the results of the various OOPP types (Table 6). Special attention is paid to the need factors as they are of main interest.

Regarding the total OOPP burden, six chronic diseases contribute to an increase in the burden in all the observed countries but with a significantly different magnitude, namely heart attack, high blood pressure, cancer, emotional disorders, rheumatoid arthritis and osteoarthritis. Other non-specified conditions also increase the total burden in the observed countries.

In terms of magnitude the largest effects can be observed for Belgium as well as the highest number of chronic diseases significantly associated with the high burden (11 specific health conditions). Considering largest effects, older people diagnosed with Parkinson disease have a by around 1.6 percentage points higher OOPP burden compared to those without this disease $(\mathrm{AME}=1.584, p<0.001)$. Being diagnosed with emotional disorders increases the OOPP burden by around 0.7 percentage points (AME $=0.708, p<0.001$ ), cancer and heart attack by around 0.6 percentage points $(\mathrm{AME}=0.619, p<0.001$, resp. $\mathrm{AME}=0.611, p<0.001)$. Osteoarthritis and chronic lung disease also have a strong and significant impact on the total OOPP burden.

In the Czech Republic, ten chronic diseases significantly increase the total burden with the largest effects for heart attack (AME $=0.556, p<0.001)$, Parkinson's disease $(\mathrm{AME}=0.524, p<0.05)$ and chronic kidney disease (AME $=0.519, p<0.01$ ), followed by a slightly lower contribution to the burden by osteoarthritis $(\mathrm{AME}=$ $0.457, p<0.001$ ).

Germany has the lowest number of chronic diseases seven - having effects on the total burden with the highest magnitude of cancer (AME $=0.726, p<0.001)$ and chronic lung disease (AME $=0.586, p<0.001$ ). Other health conditions with similar effects are heart attack, high blood pressure, emotional disorders, rheumatoid arthritis and osteoarthritis (listed in descending order according to the AMEs).

The effects of other health variables widely differ between countries. Having limitations in ADL and IADL is a significant predictor for the OOPP burden in Belgium and the Czech Republic. No effect is found for supplementary health insurance.

Regarding control variables with the highest impact, the coefficients for income show the regressive character of the OOPP burden. Compared to the first income quartile, older adults in all other quartiles spend a lower share on OOPP with the lowest share in the highest quartile (except for the second quartile in Germany which is not significantly different from the first one). Comparing the countries, the highest burden is shown for the poorest quartile in Belgium which faces a 2.3 percentage points higher burden than the richest quartile.

\section{Differences in the burden between certain types of OOPP}

When looking at the burden of OOPP for drugs, the results are only partly in accordance with the results of the total OOPP burden. The number of chronic diseases having a significant impact on the drugs burden increases in all the observed countries.

Compared to the model with total OOPP, only Alzheimer's disease and stroke are not significantly associated with the burden in Belgium. The drugs burden related to Parkinson's disease is of the highest importance compared to other conditions (a three times higher burden). In the Czech Republic, all the observed chronic diseases defined in the main model except Parkinson's disease, high blood cholesterol and Alzheimer's disease are significantly related to the drugs burden with the highest magnitude for heart attack. In Germany, the number of chronic diseases significantly influencing the burden increased to ten health conditions with the highest burden for Parkinson's disease.

Mentioning control variables with a high impact the consistent negative impact of income is reproduced for the drugs burden in all countries.

Looking at the results for the outpatient care, most of these diseases do not significantly increase the burden. In Belgium, heart attack and osteoarthritis are associated with the outpatient care burden (increasing the burden by around 0.16 to 0.14 percentage point). In the Czech Republic, only osteoarthritis (AME $=0.127, p<0.01)$ and chronic kidney disease $(\mathrm{AME}=0.253, p<0.05)$ show a significant and positive association. In Germany, relatively high AMEs are found for cancer $(\mathrm{AME}=0.428$, $p<0.01$ ) and chronic lung disease (AME $=0.447, p<$ 0.01 ) and further with a lower magnitude for high blood pressure and osteoarthritis. The negative effect of income persists for all the quartiles in Belgium, for two richest quartiles in the Czech Republic and the richest quartile in Germany. Additionally, supplementary health insurance in Belgium significantly increases the outpatient care burden.

For the inpatient OOPP burden, only stroke is significantly associated with the inpatient care burden in 
Table 5 Average marginal effects (AMEs) of the independent variables on the total OOPP burden

\begin{tabular}{|c|c|c|c|}
\hline \multirow[t]{2}{*}{ Variables } & \multicolumn{3}{|c|}{ Total OOPP burden } \\
\hline & $\mathrm{BE}$ & $C Z$ & $\mathrm{DE}$ \\
\hline Male gender ${ }^{a}$ & $-0.412^{* * *}(0.0773)$ & $-0.322^{* * *}(0.0603)$ & $-0.210^{* *}(0.0773)$ \\
\hline \multicolumn{4}{|l|}{ Age $^{\mathrm{b}}$} \\
\hline$\cdot 65-79$ & $0.202^{*}(0.0807)$ & $-0.113(0.0675)$ & $0.0679(0.0778)$ \\
\hline$\cdot 80+$ & $0.351^{* *}(0.134)$ & $-0.122(0.109)$ & $0.229(0.143)$ \\
\hline \multicolumn{4}{|l|}{ Marital status ${ }^{c}$} \\
\hline - separated & $-0.119(0.107)$ & $0.0750(0.104)$ & $-0.0372(0.133)$ \\
\hline - never married & $-0.133(0.213)$ & $-0.103(0.201)$ & $-0.0241(0.169)$ \\
\hline - widowed & $-0.407^{* * *}(0.100)$ & $-0.112(0.0842)$ & $-0.163(0.110)$ \\
\hline \multicolumn{4}{|l|}{ Education $^{d}$} \\
\hline - secondary & $0.182(0.0955)$ & $0.217^{* * * *}(0.0614)$ & $0.272^{*}(0.124)$ \\
\hline • tertiary & $0.258^{* *}(0.0953)$ & $0.513^{* * *}(0.0908)$ & $0.463^{* * *}(0.136)$ \\
\hline \multicolumn{4}{|l|}{ Income $e^{e}$} \\
\hline - 2nd quartile & $-1.030^{* * *}(0.139)$ & $-0.581^{* * *}(0.106)$ & $-0.134(0.134)$ \\
\hline - 3rd quartile & $-1.623^{* * *}(0.138)$ & $-0.981^{* * *}(0.103)$ & $-0.460^{* * *}(0.123)$ \\
\hline - 4th quartile & $-2.241^{* * *}(0.135)$ & $-1.379^{* * *}(0.0997)$ & $-1.011^{* * *}(0.117)$ \\
\hline Heart attack & $0.611^{* * *}(0.103)$ & $0.556^{* * *}(0.0887)$ & $0.365^{* *}(0.118)$ \\
\hline High blood pressure & $0.359^{* * * *}(0.0771)$ & $0.376^{* * *}(0.0600)$ & $0.336^{* * *}(0.0822)$ \\
\hline \multirow[t]{2}{*}{ High blood cholesterol } & $0.209^{* *}$ & 0.0339 & -0.104 \\
\hline & $(0.0782)$ & $(0.0686)$ & $(0.0882)$ \\
\hline Stroke & $0.281(0.187)$ & $0.280(0.155)$ & $0.328(0.169)$ \\
\hline Diabetes & $0.478^{* * *}(0.106)$ & $0.379^{* * *}(0.0724)$ & $0.0795(0.0959)$ \\
\hline Lung disease & $0.588^{* * *}(0.126)$ & $0.149(0.107)$ & $0.586^{* * *}(0.163)$ \\
\hline Cancer & $0.619^{* * *}(0.147)$ & $0.333^{* *}(0.127)$ & $0.726^{* * *}(0.177)$ \\
\hline Ulcer & $0.226(0.133)$ & $0.0990(0.149)$ & $0.0462(0.189)$ \\
\hline Parkinson & $1.584^{* * *}(0.355)$ & $0.524^{*}(0.252)$ & $0.486(0.341)$ \\
\hline Cataracts & $0.398^{* *}(0.147)$ & $0.254^{*}(0.101)$ & $0.140(0.140)$ \\
\hline Alzheimer & $0.132(0.262)$ & $-0.101(0.203)$ & $0.271(0.233)$ \\
\hline Emotional disorders & $0.708^{* * *}(0.127)$ & $0.375^{* *}(0.128)$ & $0.330^{*}(0.144)$ \\
\hline Rheumatoid Arthritis & $0.393^{* *}(0.141)$ & $0.212^{*}(0.0976)$ & $0.311^{* *}(0.110)$ \\
\hline Osteoarthritis & $0.589^{* * *}(0.0787)$ & $0.457^{* * *}(0.0650)$ & $0.276^{* *}(0.0914)$ \\
\hline Chronic kidney disease & $0.273(0.191)$ & $0.519^{* *}(0.193)$ & $0.0891(0.206)$ \\
\hline Other conditions & $0.589^{* * *}(0.0951)$ & $0.387^{* * *}(0.0718)$ & $0.364^{* * *}(0.0831)$ \\
\hline$A D L$ & $0.302^{*}(0.121)$ & $0.370^{* * *}(0.0983)$ & $0.0610(0.148)$ \\
\hline IADL & $0.381^{* * *}(0.0990)$ & $0.259^{* *}(0.0818)$ & $-0.0479(0.122)$ \\
\hline Suppl. health insurance ${ }^{f}$ & $0.128(0.0900)$ & $-0.0232(0.122)$ & $0.146(0.0798)$ \\
\hline
\end{tabular}

Note: standard errors in parentheses; ${ }^{*} p<0.05, * * p<0.01$, *** $p<0.001$

Reference categories: ${ }^{a}$ female gender, ${ }^{b} 50-64,{ }^{c}$ cohabitation, ${ }^{d}$ none/primary, ${ }^{e} 1$ st quartile, ${ }^{f}$ no supplementary insurance

Belgium. Moreover, supplementary health insurance protects from a high inpatient care burden. In the Czech Republic, being diagnosed with Parkinson's disease, cancer, stroke and emotional disorders increase the burden for inpatient care even if AME's are very low (ranging from 0.10 to 0.04$)$. In Germany, seven health diseases are associated with an increasing burden for inpatient care, however, the effects are very small, among them with the highest effects for stroke and cancer. Income is a significant predictor for inpatient care only in Belgium and Germany (with around half smaller effects compared to Belgium) for the two richest quartiles (a regressive character persists). 
Table 6 Average marginal effects (AME) of the independent variables on drugs, outpatient and inpatient care burden

\begin{tabular}{|c|c|c|c|c|c|c|c|c|c|}
\hline \multirow[t]{2}{*}{ Variables } & \multicolumn{3}{|c|}{ Drugs burden } & \multicolumn{3}{|c|}{ Outpatient care burden } & \multicolumn{3}{|c|}{ Inpatient care burden } \\
\hline & $\mathrm{BE}$ & $\mathrm{CZ}$ & $\mathrm{DE}$ & $\mathrm{BE}$ & $\mathrm{CZ}$ & DE & $\mathrm{BE}$ & $\mathrm{CZ}$ & $\mathrm{DE}$ \\
\hline Male gender ${ }^{a}$ & $\begin{array}{l}-0.186^{* * *} \\
(0.0417)\end{array}$ & $\begin{array}{l}-0.117^{* * *} \\
(0.0337)\end{array}$ & $\begin{array}{l}-0.0245 \\
(0.0188)\end{array}$ & $\begin{array}{l}-0.183^{* * *} \\
(0.0411)\end{array}$ & $\begin{array}{l}-0.133^{* *} \\
(0.0429)\end{array}$ & $\begin{array}{l}-0.184^{* *} \\
(0.0661)\end{array}$ & $\begin{array}{l}-0.0297 \\
(0.0290)\end{array}$ & $\begin{array}{l}-0.0436^{* * *} \\
(0.0121)\end{array}$ & $\begin{array}{l}0.0306^{*} \\
(0.0152)\end{array}$ \\
\hline \multicolumn{10}{|l|}{ Age $^{\mathrm{b}}$} \\
\hline$-65-79$ & $\begin{array}{l}0.162^{* * *} \\
(0.0431)\end{array}$ & $\begin{array}{l}0.0177 \\
(0.0363)\end{array}$ & $\begin{array}{l}0.0222 \\
(0.0187)\end{array}$ & $\begin{array}{l}0.000619 \\
(0.0444)\end{array}$ & $\begin{array}{l}-0.119^{*} \\
(0.0479)\end{array}$ & $\begin{array}{l}0.0276 \\
(0.0661)\end{array}$ & $\begin{array}{l}0.0779^{*} \\
(0.0318)\end{array}$ & $\begin{array}{l}0.0223 \\
(0.0129)\end{array}$ & $\begin{array}{l}0.0135 \\
(0.0151)\end{array}$ \\
\hline$-80+$ & $\begin{array}{l}0.272^{* * *} \\
(0.0763)\end{array}$ & $\begin{array}{l}0.0923 \\
(0.0701)\end{array}$ & $\begin{array}{l}0.0871^{*} \\
(0.0374)\end{array}$ & $\begin{array}{l}0.0177 \\
(0.0733)\end{array}$ & $\begin{array}{l}-0.218^{* *} \\
(0.0687)\end{array}$ & $\begin{array}{l}0.108 \\
(0.127)\end{array}$ & $\begin{array}{l}0.102^{*} \\
(0.0482)\end{array}$ & $\begin{array}{l}0.0405 \\
(0.0229)\end{array}$ & $\begin{array}{l}0.0282 \\
(0.0285)\end{array}$ \\
\hline \multicolumn{10}{|l|}{ Marital status ${ }^{c}$} \\
\hline - separated & $\begin{array}{l}-0.0118 \\
(0.0576)\end{array}$ & $\begin{array}{l}-0.0595 \\
(0.0540)\end{array}$ & $\begin{array}{l}-0.0350 \\
(0.0301)\end{array}$ & $\begin{array}{l}-0.134^{*} \\
(0.0538)\end{array}$ & $\begin{array}{l}0.0980 \\
(0.0751)\end{array}$ & $\begin{array}{l}-0.0366 \\
(0.116)\end{array}$ & $\begin{array}{l}0.00275 \\
(0.0428)\end{array}$ & $\begin{array}{l}0.0245 \\
(0.0224)\end{array}$ & $\begin{array}{l}0.0543 \\
(0.0296)\end{array}$ \\
\hline $\begin{array}{c}\text { - never } \\
\text { married }\end{array}$ & $\begin{array}{l}-0.139 \\
(0.0879)\end{array}$ & $\begin{array}{l}-0.0109 \\
(0.124)\end{array}$ & $\begin{array}{l}-0.0736 \\
(0.0383)\end{array}$ & $\begin{array}{l}-0.0867 \\
(0.102)\end{array}$ & $\begin{array}{l}-0.140 \\
(0.103)\end{array}$ & $\begin{array}{l}0.0746 \\
(0.159)\end{array}$ & $0.118(0.106)$ & $\begin{array}{l}0.0636 \\
(0.0507)\end{array}$ & $\begin{array}{l}-0.0252 \\
(0.0202)\end{array}$ \\
\hline - widowed & $\begin{array}{l}-0.186^{* *} \\
(0.0575)\end{array}$ & $\begin{array}{l}-0.0451 \\
(0.0494)\end{array}$ & $\begin{array}{l}-0.0264 \\
(0.0322)\end{array}$ & $\begin{array}{l}-0.215^{* * *} \\
(0.0530)\end{array}$ & $\begin{array}{l}-0.0828 \\
(0.0565)\end{array}$ & $\begin{array}{l}-0.182^{*} \\
(0.0906)\end{array}$ & $\begin{array}{l}-0.0223 \\
(0.0351)\end{array}$ & $\begin{array}{l}0.00951 \\
(0.0177)\end{array}$ & $\begin{array}{l}0.0576^{*} \\
(0.0292)\end{array}$ \\
\hline \multicolumn{10}{|l|}{ Education $^{d}$} \\
\hline - secondary & $\begin{array}{l}0.00650 \\
(0.0520)\end{array}$ & $\begin{array}{l}-0.0146 \\
(0.0356)\end{array}$ & $\begin{array}{l}0.0443 \\
(0.0304)\end{array}$ & $\begin{array}{l}0.144^{* *} \\
(0.0495)\end{array}$ & $\begin{array}{l}0.194^{* * *} \\
(0.0427)\end{array}$ & $\begin{array}{l}0.236^{*} \\
(0.0991)\end{array}$ & $\begin{array}{l}0.0411 \\
(0.0380)\end{array}$ & $\begin{array}{l}0.0290^{*} \\
(0.0119)\end{array}$ & $\begin{array}{l}0.0310 \\
(0.0190)\end{array}$ \\
\hline - tertiary & $\begin{array}{l}0.0260 \\
(0.0523)\end{array}$ & $\begin{array}{l}0.0892 \\
(0.0525)\end{array}$ & $\begin{array}{l}0.0545 \\
(0.0332)\end{array}$ & $\begin{array}{l}0.232^{* * *} \\
(0.0516)\end{array}$ & $\begin{array}{l}0.342^{* * *} \\
(0.0621)\end{array}$ & $\begin{array}{l}0.456^{* * *} \\
(0.113)\end{array}$ & $\begin{array}{l}-0.00461 \\
(0.0333)\end{array}$ & $\begin{array}{l}0.0955^{* * *} \\
(0.0290)\end{array}$ & $\begin{array}{l}-0.00640 \\
(0.0199)\end{array}$ \\
\hline \multicolumn{10}{|l|}{ Income $e^{e}$} \\
\hline - 2nd quartile & $\begin{array}{l}-0.516^{* * *} \\
(0.0779)\end{array}$ & $\begin{array}{l}-0.485^{* * *} \\
(0.0607)\end{array}$ & $\begin{array}{l}-0.145^{* * *} \\
(0.0351)\end{array}$ & $\begin{array}{l}-0.353^{* * *} \\
(0.0750)\end{array}$ & $\begin{array}{l}-0.0938 \\
(0.0758)\end{array}$ & $\begin{array}{l}-0.0177 \\
(0.125)\end{array}$ & $\begin{array}{l}-0.0492 \\
(0.0506)\end{array}$ & $\begin{array}{l}0.00579 \\
(0.0180)\end{array}$ & $\begin{array}{l}0.0119 \\
(0.0259)\end{array}$ \\
\hline - 3rd quartile & $\begin{array}{l}-0.836^{* * *} \\
(0.0742)\end{array}$ & $\begin{array}{l}-0.695^{* * *} \\
(0.0606)\end{array}$ & $\begin{array}{l}-0.271^{* * *} \\
(0.0326)\end{array}$ & $\begin{array}{l}-0.558^{* * *} \\
(0.0775)\end{array}$ & $\begin{array}{l}-0.265^{* * *} \\
(0.0697)\end{array}$ & $\begin{array}{l}-0.164 \\
(0.115)\end{array}$ & $\begin{array}{l}-0.165^{* * *} \\
(0.0473)\end{array}$ & $\begin{array}{l}-0.0109 \\
(0.0192)\end{array}$ & $\begin{array}{l}-0.0479^{*} \\
(0.0231)\end{array}$ \\
\hline - 4th quartile & $\begin{array}{l}-1.278^{* * *} \\
(0.0706)\end{array}$ & $\begin{array}{l}-0.979^{* * *} \\
(0.0560)\end{array}$ & $\begin{array}{l}-0.470^{* * *} \\
(0.0310)\end{array}$ & $\begin{array}{l}-0.749^{* * *} \\
(0.0761)\end{array}$ & $\begin{array}{l}-0.362^{* * *} \\
(0.0676)\end{array}$ & $\begin{array}{l}-0.469^{* * *} \\
(0.108)\end{array}$ & $\begin{array}{l}-0.192^{* * *} \\
(0.0473)\end{array}$ & $\begin{array}{l}-0.00497 \\
(0.0171)\end{array}$ & $\begin{array}{l}-0.0917^{* * * *} \\
(0.0232)\end{array}$ \\
\hline Heart attack & $\begin{array}{l}0.419^{* * *} \\
(0.0647)\end{array}$ & $\begin{array}{l}0.475^{* * *} \\
(0.0564)\end{array}$ & $\begin{array}{l}0.175^{* * *} \\
(0.0299)\end{array}$ & $\begin{array}{l}0.139^{*} \\
(0.0544)\end{array}$ & $\begin{array}{l}0.0405 \\
(0.0640)\end{array}$ & $\begin{array}{l}0.0437 \\
(0.109)\end{array}$ & $\begin{array}{l}0.0513 \\
(0.0341)\end{array}$ & $\begin{array}{l}-0.000490 \\
(0.0138)\end{array}$ & $\begin{array}{l}0.0835^{* * *} \\
(0.0204)\end{array}$ \\
\hline $\begin{array}{l}\text { High blood } \\
\text { pressure }\end{array}$ & $\begin{array}{l}0.290^{* * *} \\
(0.0428)\end{array}$ & $\begin{array}{l}0.342^{* * *} \\
(0.0337)\end{array}$ & $\begin{array}{l}0.108^{* * *} \\
(0.0180)\end{array}$ & $\begin{array}{l}0.0386 \\
(0.0403)\end{array}$ & $\begin{array}{l}0.0439 \\
(0.0426)\end{array}$ & $\begin{array}{l}0.214^{* *} \\
(0.0712)\end{array}$ & $\begin{array}{l}0.0262 \\
(0.0288)\end{array}$ & $\begin{array}{l}0.00485 \\
(0.0129)\end{array}$ & $\begin{array}{l}0.0331^{*} \\
(0.0140)\end{array}$ \\
\hline High cholesterol & $\begin{array}{l}0.163^{* * *} \\
(0.0426)\end{array}$ & $\begin{array}{l}0.0514 \\
(0.0389)\end{array}$ & $\begin{array}{l}0.0340 \\
(0.0215)\end{array}$ & $\begin{array}{l}0.0187 \\
(0.0419)\end{array}$ & $\begin{array}{l}-0.0440 \\
(0.0460)\end{array}$ & $\begin{array}{l}-0.132 \\
(0.0790)\end{array}$ & $\begin{array}{l}0.0242 \\
(0.0324)\end{array}$ & $\begin{array}{l}0.0113 \\
(0.0141)\end{array}$ & $\begin{array}{l}-0.00481 \\
(0.0172)\end{array}$ \\
\hline Stroke & $0.149(0.102)$ & $\begin{array}{l}0.190^{*} \\
(0.0889)\end{array}$ & $\begin{array}{l}0.167^{* *} \\
(0.0514)\end{array}$ & $\begin{array}{l}-0.0415 \\
(0.0817)\end{array}$ & $\begin{array}{l}-0.00509 \\
(0.115)\end{array}$ & $\begin{array}{l}-0.0226 \\
(0.144)\end{array}$ & $\begin{array}{l}0.136^{*} \\
(0.0586)\end{array}$ & $\begin{array}{l}0.0425^{*} \\
(0.0215)\end{array}$ & $\begin{array}{l}0.101^{* *} \\
(0.0338)\end{array}$ \\
\hline Diabetes & $\begin{array}{l}0.362^{* * *} \\
(0.0660)\end{array}$ & $\begin{array}{l}0.327^{* * *} \\
(0.0441)\end{array}$ & $\begin{array}{l}0.177^{* * *} \\
(0.0268)\end{array}$ & $\begin{array}{l}0.0907 \\
(0.0557)\end{array}$ & $\begin{array}{l}0.0508 \\
(0.0503)\end{array}$ & $\begin{array}{l}-0.126 \\
(0.0917)\end{array}$ & $\begin{array}{l}0.0434 \\
(0.0386)\end{array}$ & $\begin{array}{l}-0.0117 \\
(0.0133)\end{array}$ & $\begin{array}{l}0.0358 \\
(0.0200)\end{array}$ \\
\hline Lung disease & $\begin{array}{l}0.470^{* * *} \\
(0.0762)\end{array}$ & $\begin{array}{l}0.201^{* *} \\
(0.0682)\end{array}$ & $\begin{array}{l}0.162^{* * *} \\
(0.0324)\end{array}$ & $\begin{array}{l}-0.0147 \\
(0.0570)\end{array}$ & $\begin{array}{l}-0.0555 \\
(0.0683)\end{array}$ & $\begin{array}{l}0.447^{* *} \\
(0.145)\end{array}$ & $\begin{array}{l}0.0699 \\
(0.0456)\end{array}$ & $\begin{array}{l}0.0116 \\
(0.0204)\end{array}$ & $\begin{array}{l}0.0299 \\
(0.0206)\end{array}$ \\
\hline Cancer & $\begin{array}{l}0.402^{* * *} \\
(0.0944)\end{array}$ & $\begin{array}{l}0.318^{* * *} \\
(0.0837)\end{array}$ & $\begin{array}{l}0.180^{* * *} \\
(0.0448)\end{array}$ & $\begin{array}{l}0.126 \\
(0.0644)\end{array}$ & $\begin{array}{l}-0.00712 \\
(0.0731)\end{array}$ & $\begin{array}{l}0.428^{* *} \\
(0.152)\end{array}$ & $\begin{array}{l}0.0549 \\
(0.0504)\end{array}$ & $\begin{array}{l}0.0550^{*} \\
(0.0249)\end{array}$ & $\begin{array}{l}0.0951^{* * *} \\
(0.0270)\end{array}$ \\
\hline Ulcer & $\begin{array}{l}0.242^{* *} \\
(0.0749)\end{array}$ & $\begin{array}{l}0.211^{*} \\
(0.0947)\end{array}$ & $\begin{array}{l}0.105 \\
(0.0671)\end{array}$ & $\begin{array}{l}-0.00246 \\
(0.0672)\end{array}$ & $\begin{array}{l}-0.130 \\
(0.105)\end{array}$ & $\begin{array}{l}-0.0558 \\
(0.158)\end{array}$ & $\begin{array}{l}0.00906 \\
(0.0493)\end{array}$ & $\begin{array}{l}-0.00952 \\
(0.0213)\end{array}$ & $\begin{array}{l}0.0303 \\
(0.0367)\end{array}$ \\
\hline Parkinson & $\begin{array}{l}1.202^{* * * *} \\
(0.251)\end{array}$ & $0.259(0.160)$ & $\begin{array}{l}0.262^{*} \\
(0.116)\end{array}$ & $0.318(0.199)$ & $\begin{array}{l}0.0971 \\
(0.170)\end{array}$ & $\begin{array}{l}0.0915 \\
(0.236)\end{array}$ & $\begin{array}{l}0.0751 \\
(0.101)\end{array}$ & $\begin{array}{l}0.0952^{*} \\
(0.0422)\end{array}$ & $\begin{array}{l}0.0451 \\
(0.0465)\end{array}$ \\
\hline Cataracts & $\begin{array}{l}0.193^{*} \\
(0.0854)\end{array}$ & $\begin{array}{l}0.133^{*} \\
(0.0565)\end{array}$ & $\begin{array}{l}0.0282 \\
(0.0308)\end{array}$ & $\begin{array}{l}0.144 \\
(0.0782)\end{array}$ & $\begin{array}{l}0.110 \\
(0.0720)\end{array}$ & $\begin{array}{l}0.124 \\
(0.122)\end{array}$ & $\begin{array}{l}0.00390 \\
(0.0437)\end{array}$ & $\begin{array}{l}-0.0169 \\
(0.0194)\end{array}$ & $\begin{array}{l}-0.0195 \\
(0.0225)\end{array}$ \\
\hline Alzheimer & $0.115(0.177)$ & $\begin{array}{l}0.0187 \\
(0.133)\end{array}$ & $\begin{array}{l}0.148 \\
(0.0906)\end{array}$ & $\begin{array}{l}-0.129 \\
(0.129)\end{array}$ & $\begin{array}{l}-0.192 \\
(0.142)\end{array}$ & $\begin{array}{l}0.202 \\
(0.224)\end{array}$ & $\begin{array}{l}0.0463 \\
(0.0920)\end{array}$ & $\begin{array}{l}-0.0259 \\
(0.0397)\end{array}$ & $\begin{array}{l}0.0352 \\
(0.0412)\end{array}$ \\
\hline $\begin{array}{l}\text { Emotional } \\
\text { disorders }\end{array}$ & $\begin{array}{l}0.465^{* * *} \\
(0.0704)\end{array}$ & $\begin{array}{l}0.274^{* * *} \\
(0.0805)\end{array}$ & $\begin{array}{l}0.130^{* * *} \\
(0.0322)\end{array}$ & $\begin{array}{l}0.116 \\
(0.0645)\end{array}$ & $\begin{array}{l}0.0612 \\
(0.0957)\end{array}$ & $\begin{array}{l}0.139 \\
(0.147)\end{array}$ & $\begin{array}{l}0.0760 \\
(0.0470)\end{array}$ & $\begin{array}{l}0.0436^{*} \\
(0.0176)\end{array}$ & $\begin{array}{l}0.0501^{*} \\
(0.0215)\end{array}$ \\
\hline Rheum. Arthritis & $\begin{array}{l}0.298^{* * *} \\
(0.0829)\end{array}$ & $\begin{array}{l}0.182^{* * *} \\
(0.0548)\end{array}$ & $\begin{array}{l}0.137^{* * *} \\
(0.0320)\end{array}$ & $\begin{array}{l}0.0801 \\
(0.0722)\end{array}$ & $\begin{array}{l}0.0187 \\
(0.0733)\end{array}$ & $\begin{array}{l}0.0933 \\
(0.0953)\end{array}$ & $\begin{array}{l}-0.0189 \\
(0.0459)\end{array}$ & $\begin{array}{l}-0.00128 \\
(0.0179)\end{array}$ & $\begin{array}{l}0.0622^{* *} \\
(0.0216)\end{array}$ \\
\hline
\end{tabular}


Table 6 Average marginal effects (AME) of the independent variables on drugs, outpatient and inpatient care burden (Continued)

\begin{tabular}{|c|c|c|c|c|c|c|c|c|c|}
\hline \multirow[t]{2}{*}{ Variables } & \multicolumn{3}{|c|}{ Drugs burden } & \multicolumn{3}{|c|}{ Outpatient care burden } & \multicolumn{3}{|c|}{ Inpatient care burden } \\
\hline & $\mathrm{BE}$ & $\mathrm{CZ}$ & $\mathrm{DE}$ & $\mathrm{BE}$ & $\mathrm{CZ}$ & $\mathrm{DE}$ & $\mathrm{BE}$ & $\mathrm{CZ}$ & $\mathrm{DE}$ \\
\hline Osteoarthritis & $\begin{array}{l}0.375^{* * *} \\
(0.0432)\end{array}$ & $\begin{array}{l}0.320^{* * *} \\
(0.0376)\end{array}$ & $\begin{array}{l}0.0897^{* * *} \\
(0.0216)\end{array}$ & $\begin{array}{l}0.163^{* * *} \\
(0.0416)\end{array}$ & $\begin{array}{l}0.127^{* *} \\
(0.0458)\end{array}$ & $\begin{array}{l}0.171^{*} \\
(0.0786)\end{array}$ & $\begin{array}{l}0.0350 \\
(0.0302)\end{array}$ & $\begin{array}{l}0.0238 \\
(0.0139)\end{array}$ & $\begin{array}{l}0.0389^{*} \\
(0.0163)\end{array}$ \\
\hline $\begin{array}{l}\text { Chronic kidney } \\
\text { dis. }\end{array}$ & $\begin{array}{l}0.356^{* *} \\
(0.127)\end{array}$ & $\begin{array}{l}0.278^{*} \\
(0.111)\end{array}$ & $\begin{array}{l}0.0688 \\
(0.0696)\end{array}$ & $\begin{array}{l}-0.0862 \\
(0.103)\end{array}$ & $\begin{array}{l}0.253^{*} \\
(0.123)\end{array}$ & $\begin{array}{l}-0.0239 \\
(0.189)\end{array}$ & $\begin{array}{l}-0.0276 \\
(0.0598)\end{array}$ & $\begin{array}{l}0.00802 \\
(0.0258)\end{array}$ & $\begin{array}{l}-0.0141 \\
(0.0310)\end{array}$ \\
\hline Other conditions & $\begin{array}{l}0.395^{* * *} \\
(0.0529)\end{array}$ & $\begin{array}{l}0.335^{* * *} \\
(0.0417)\end{array}$ & $\begin{array}{l}0.168^{* * *} \\
(0.0224)\end{array}$ & $\begin{array}{l}0.146^{* *} \\
(0.0487)\end{array}$ & $\begin{array}{l}0.0313 \\
(0.0489)\end{array}$ & $\begin{array}{l}0.180^{*} \\
(0.0720)\end{array}$ & $\begin{array}{l}0.0495 \\
(0.0324)\end{array}$ & $\begin{array}{l}0.0241 \\
(0.0150)\end{array}$ & $\begin{array}{l}0.0440^{* *} \\
(0.0152)\end{array}$ \\
\hline ADL & $\begin{array}{l}0.0828 \\
(0.0681)\end{array}$ & $\begin{array}{l}0.299^{* * *} \\
(0.0644)\end{array}$ & $\begin{array}{l}0.0211 \\
(0.0351)\end{array}$ & $\begin{array}{l}0.0198 \\
(0.0608)\end{array}$ & $\begin{array}{l}-0.0445 \\
(0.0668)\end{array}$ & $\begin{array}{l}-0.00492 \\
(0.132)\end{array}$ & $\begin{array}{l}0.153^{* * *} \\
(0.0394)\end{array}$ & $\begin{array}{l}0.0477^{* *} \\
(0.0173)\end{array}$ & $\begin{array}{l}0.00911 \\
(0.0266)\end{array}$ \\
\hline IADL & $\begin{array}{l}0.358^{* * *} \\
(0.0588)\end{array}$ & $\begin{array}{l}0.315^{* * *} \\
(0.0529)\end{array}$ & $\begin{array}{l}0.0859^{* *} \\
(0.0326)\end{array}$ & $\begin{array}{l}0.0149 \\
(0.0532)\end{array}$ & $\begin{array}{l}-0.135^{*} \\
(0.0549)\end{array}$ & $\begin{array}{l}-0.238^{*} \\
(0.119)\end{array}$ & $\begin{array}{l}0.0173 \\
(0.0335)\end{array}$ & $\begin{array}{l}0.0357^{*} \\
(0.0162)\end{array}$ & $\begin{array}{l}0.0565^{*} \\
(0.0229)\end{array}$ \\
\hline $\begin{array}{l}\text { Suppl. health } \\
\text { insurance. }\end{array}$ & $\begin{array}{l}0.0624 \\
(0.0493)\end{array}$ & $\begin{array}{l}-0.0497 \\
(0.0611)\end{array}$ & $\begin{array}{l}0.0297 \\
(0.0187)\end{array}$ & $\begin{array}{l}0.141^{* *} \\
(0.0442)\end{array}$ & $\begin{array}{l}0.0347 \\
(0.0874)\end{array}$ & $\begin{array}{l}0.109 \\
(0.0695)\end{array}$ & $\begin{array}{l}-0.152^{* * *} \\
(0.0438)\end{array}$ & $\begin{array}{l}0.00315 \\
(0.0233)\end{array}$ & $\begin{array}{l}-0.00829 \\
(0.0142)\end{array}$ \\
\hline
\end{tabular}

Note: standard errors in parentheses; ${ }^{*} p<0.05, * * 0<0.01, * * * 0<0.001$

Reference categories: ${ }^{a}$ female gender, ${ }^{b} 50-64,{ }^{c}$ cohabitation, ${ }^{d}$ none/primary, ${ }^{e} 1$ st quartile, ${ }^{f}$ no supplementary insurance

\section{Discussion}

The OOPP burden varies with chronic diseases and has different magnitudes in the observed countries. Nevertheless, some patterns can be found. The main joint association of the high OOPP burden and chronic diseases is found for heart attack, high blood pressure, cancer, emotional disorders, rheumatoid arthritis and osteoarthritis. Previous research based on SHARE data also found that cardiovascular diseases are a significant predictor for very high (catastrophic) OOPP payments in Belgium and the Czech Republic [10]. Further, the SHARE postdeath survey showed that cardiovascular diseases and malignant neoplasms are the most frequent cause of death for older adults [44]. Taking into account the fact that cardiovascular diseases and musculoskeletal disorders are most prevalent in the older population of the observed countries, policy makers should pay special attention to these diseases when they target methods to protect older people from the high OOPP burden.

It is obvious that country differences in the burden of particular diseases are a sign of different health care reimbursements and cost sharing policies. Belgium has a complex cost sharing policy with a high share of supplementary and direct payments which are not included in the protective maximum limit. Only co-payments and co-insurance are included to the limit which may imply that inequalities in the distribution of the OOPP burden for a large number of diseases exist as shown in our study. Even if protective measures are quite extensive in the Belgian health care system they might not be as effective as expected which also a relatively recent study on equity in the Belgian health care system confirms [48]. Based on our findings, the drugs burden should be of particular interest as the majority of chronic conditions increase it with a special focus on drugs related to Parkinson's disease. Large costs (including high supplementary payments) can be applied to hospitalisation in the Belgian health care system, however, we found that only having stroke is significantly associated with the inpatient care burden. It seems that supplementary insurance works well in this regard and our finding about a negative association with the inpatient care burden supports it.

In Germany, cancer and chronic lung disease were identified as the diseases with the largest magnitude, which is especially due to the outpatient care burden. This might be related to co-payments for transport services and nonphysician services which are common. It is worth highlighting that even if Parkinson's disease is not related to the overall burden, it has the highest magnitude for the drugs burden. Thus, prescription practices in relation to Parkinson's disease should be examined. A closer look at the inpatient care burden would also be desirable. Even if the burden is low, most diseases were positively associated with it. In particular, co-payments for inpatient stays can further contribute to a high burden for older adults having cancer and heart attack. Thus, it seems that charges per inpatient stay can disproportionally burden patients with some chronic conditions even if a maximum for inpatient stay charges is applied.

In the Czech Republic, mostly OOPP for drugs are common in the health care system which coincide with our findings that the drugs burden should be revised in order to lower the burden for older adults (especially drugs which prevent heart attack). Czech politicians recognise that people should be protected from the high OOPP burden but currently, only one protective mechanism in the form of the OOPP maximum limit for drug co-payments is applied. However, its function can be curbed because not all co-payments are included within the limit. It is applied only to co-payments for prescribed drugs and only about one third of prescribed 
drugs are eligible for the limit. Thus, older people consuming drugs from the remaining two-thirds of medication items are realistically not protected. Moreover, payments for OTC pharmaceuticals are not monitored, however, they play an important role in total OOPP for drugs based on the official statistics [49]. For individuals aged 65 and more, a lowered maximum for drug copayments is applied. Nevertheless, age is the only criterion and as the findings about age show, this consideration might be appropriate only to a certain extent. Regarding the outpatient and inpatient care the majority of services are covered which is in accordance with our results. In the outpatient care some direct payments can occur in relation to services of private clinics (e. g. physiotherapists, fees for application of intra-articular injections). OOPP for inpatient care are mostly related only to above-standard room services in the Czech health care system which might explain an association of several diseases with the inpatient care burden but the impact on the overall burden is rather negligible.

We conclude that the impact of specific chronic diseases on the OOPP burden differs between the types of OOPP, and that coping with the drugs burden should have a special priority as the majority of observed diseases are associated with an increasing drugs burden in all three countries. However, other types of OOPP burden can be relevant for some diseases as well. Our findings point out that a focus on the effect of the OOPP types is necessary. Without it, the interpretation of findings for specific chronic conditions could be inaccurate as suggested above.

In addition, we found that the economic situation of older adults is a highly relevant predictor. A regressive pattern of OOPP burden is found in all three countries and is confirmed by findings in previous studies of the older population $[19,32,45]$. This finding shows that income constitutes the best protection against the OOPP burden in all three countries. Income protection is missing in the Czech Republic, thus implementing this mechanism might substantially lower the burden for low-income households. However, setting a correct threshold is essential since our findings showed that even if income protection is implemented and directly related to gross income in Germany, it does not work as protectively as expected. A revision of the threshold seems to be desirable for the poorest, especially. The protection of low-income households is also insufficient in Belgium even if the OOPP maximum is structured according to income. Thus, based on our findings, current income protection implemented in the health care system does not counter regressiveness for older adults.

Finally, our research showed that country specifics play a role. Therefore, we focused only on three countries in more detail in this paper in order to provide a background for evaluating the implications for older adults and suggestions for countries' health and social policies. An investigation of more EU countries is open for future research.

We leave aside a more detailed discussion about the impact of other predisposing and enabling factors included in the analysis as this was not the main focus of the paper. However, some of the findings might be relevant for future research about various determinants of the OOPP burden.

We are aware of some limitations in our study. The accuracy of findings depends on the available data and its design, and although SHARE is one of the comprehensive sources for investigating older adults currently, we are not able to address accurately several aspects. Firstly, SHARE does not contain more detailed information on particular OOPP types (prescribed versus OTC drugs, types of outpatient care, possible informal payments, etc.). We cannot attribute a particular amount of OOPP to specific chronic diseases as the respondents are not asked about health payments in such detail. In addition, as is mentioned in the introduction, multimorbidity is usual in older age, therefore some diseases appear jointly. In order to reflect this fact, we ran cluster analysis and implemented some interaction terms in the model, but the results did not provide any additional valuable insight. This is supported by another similar study which found that observing individual chronic diseases offers better and more useful information about the OOPP burden than clusters or other groupings of diseases [19]. Secondly, after comparing reported OOPP in SHARE with OOPP reported in household budget surveys it seems that health expenditure in SHARE is underestimated, as also pointed out elsewhere [46]. The fact that reported OOPP are based on the respondent's recall and thus might be linked with better cognition for some respondents contributes to the limitations of our study. Thirdly, regarding the OOPP burden we are not able to distinguish that a part of OOPP reflects a willingness to purchase either OTC pharmaceuticals or other not covered services such as spa-treatment or preventive physiotherapy (necessary versus unnecessary health care services). Fourthly, we did not address possible unmet need due to financial constraints because only unmet need for physician's visits could have been observed. Fifthly, we used an umbrella term "chronic diseases" for observed health conditions even if some might question this classification. However, there is no generally recognised classification of chronic diseases and the list of chronic diseases differs depending on the defining body [36]. Nevertheless, all observed diseases are highly prevalent among older groups of population and require ongoing medical attention or limit activities of daily living or both. Further, we acknowledge that the empirical 
analysis might suffer from the endogeneity of some of our explanatory variables, such as income and education. Lastly, it is obvious from the results that the group of other health conditions (chronic and non-chronic) for which we cannot estimate the effect separately play a role as well.

\section{Conclusions}

Specific chronic diseases increase the overall OOPP burden in the observed countries with a strong association for the drug burden. The diseases increasing the overall burden in Belgium, the Czech Republic and Germany are heart attack, high blood pressure, cancer, emotional disorders, rheumatoid arthritis and osteoarthritis. Reflecting country differences, it is worth paying attention to Parkinson's disease and its drugs burden in Belgium; to the drugs burden related to heart attack and outpatient care burden of chronic kidney disease in the Czech Republic and outpatient care burden of cancer and chronic lung disease in Germany. It seems that only individuals with Alzheimer's disease are protected well from any OOPP burden in the observed countries.

The OOPP burden is not equitably distributed among individuals with chronic diseases. Even if some protective mechanisms and exemptions from OOPP are implemented in the observed health care systems, some gaps in the protection are obvious. Disease-based protection is a specific protective feature which has to be applied on a national basis and in accordance with morbidity and cost sharing settings in each country. Conversely, incomebased protection seems to be an essential universal instrument if we focus on protecting the most vulnerable. Our study points out that evaluating and monitoring the OOPP burden not only from the socio-economic perspective (as a majority of studies do) but also from a disease aspect should be of particular interest because some of the chronic diseases increase the burden considerably.

\section{Abbreviations}

EU: European Union; OOPP: out-of-pocket payments; SHARE: Survey of Health, Ageing and Retirement in Europe; WHO: World Health Organization; ADL: limitations in basic activities of daily living; IADL: limitations in instrumental activities of daily living; EURO-D: EURO depression; SPH: selfperceived health; 2 PM: two-part model; SSM: sample selection model; GLM: generalised linear model; AME: average marginal effect

\section{Supplementary Information}

The online version contains supplementary material available at https://doi. org/10.1186/s12913-021-06259-w.

\section{Additional file 1.}

\section{Acknowledgements}

This paper uses data from SHARE Wave 6 (DOl: https://doi.org/10.6103/ SHARE.w6.700), see [27] for methodological details.

The SHARE data collection has been funded by the European Commission through FP5 (QLK6-CT-2001-00360), FP6 (SHARE-I3: RII-CT-2006-062193, COMPARE: CIT5-CT-2005-028857, SHARELIFE: CIT4-CT-2006-028812), FP7 (SHAREPREP: GA N²11909, SHARE-LEAP: GA N²27822, SHCARE M4: GA №261982) and Horizon 2020 (SHARE-DEV3: GA No676536, SERISS: GA No654221) and by DG Employment, Social Affairs \& Inclusion. Additional funding from the German Ministry of Education and Research, the Max Planck Society for the Advancement of Science, the U.S. National Institute on Aging (U01_AG0974013S2, P01_AG005842, P01_AG08291, P30_AG12815, R21_AG025169, Y1-AG4553-01, IAG_BSR06-11, OGHA_04-064, HHSN271201300071C) and from various national funding sources is gratefully acknowledged (see www.shareproject.org).

\section{Authors' contributions}

LB and VKK did the data preparation. LB performed the data analyses and VKK wrote the first draft of the article. All authors contributed to the interpretation of the results and assisted in the preparation of the manuscript. All authors read and approved the manuscript.

Funding

Not applicable.

Availability of data and materials

The data used in the analyses are accessible from the SHARE website http:// share-project.org/home0.html.

\section{Declarations}

Ethics approval and consent to participate

Not applicable.

\section{Consent for publication}

Not applicable.

\section{Competing interests}

Not applicable.

\section{Author details}

${ }^{1}$ Faculty of Business and Economics, Mendel University in Brno, Zemedelska 1, 61300 Brno, Czech Republic. Institute for Public Finance and Social Policy, Albert-Ludwigs-University of Freiburg, P.O. Box, 79085 Freiburg, Germany. ${ }^{3}$ Faculty of Business and Economics, University of Antwerp, Prinsstraat 13, 2000 Antwerp, Belgium.

Received: 24 September 2020 Accepted: 8 March 2021

Published online: 17 March 2021

\section{References}

1. World Health Organization (WHO). Global Health Estimates 2016: Disease burden by cause, age, sex, by country and by region, 2000-2016. Geneva: WHO; 2018. https://www.who.int/healthinfo/global_burden_disease/estima tes/en/. Accessed 20 Feb 2020.

2. Abegunde DO, Stanciole AE. The economic impact of chronic diseases: how do households respond to shocks? Evidence from Russia. Soc Sci Med. 2008;66(11):2296-307. https://doi.org/10.1016/j.socscimed.2008.01.041.

3. Jeon $\mathrm{YH}$, Essue B, Jan S, Wells R, Whitworth JA. Economic hardship associated with managing chronic illness: a qualitative inquiry. BMC Health Serv Res. 2009:9:1-11.

4. Bíró A. Copayments, gatekeeping, and the utilization of outpatient public and private care at age 50 and above in Europe. Health Policy. 2013;111(1): 24-33. https://doi.org/10.1016/j.healthpol.2013.03.009.

5. OECD/EU. Health at a Glance: Europe 2016: State of health in the EU cycle. Paris: OECD Publishing; 2016.

6. Harbers MM, Achterberg PW. Europeans of retirement age: chronic diseases and economic activity. 2012. https://ec.europa.eu/health/sites/health/files/ major_chronic_diseases/docs/rivm_report_retirement_en.pdf. Accessed 20 Feb 2020.

7. Prince MJ, Wu F, Guo Y, Gutierrez Robledo LM, O'Donnell M, Sullivan R, Yusuf S. The burden of disease in older people and implications for health policy and practice. Lancet. 2015;385(9967):549-62. https://doi.org/10.1016/ S0140-6736(14)61347-7.

8. Nielsen CR, Halling A, Andersen-Ranberg K. Disparities in multimorbidity across Europe - findings from the SHARE survey. Eur Geriatr Med. 2017:8(1): 16-21. https://doi.org/10.1016/j.eurger.2016.11.010. 
9. Paez KA, Zhao L, Hwang W. Rising out-of-pocket spending for chronic conditions: a ten-year trend. Health Aff. 2009;28(1):15-25. https://doi.org/1 0.1377/hlthaff.28.1.15.

10. Arsenijevic J, Pavlova M, Rechel B, Groot W. Catastrophic health care expenditure among older people with chronic diseases in 15 European countries. PLoS One. 2016;11:1-18.

11. Baird K. The incidence of high medical expenses by health status in seven developed countries. Health Policy. 2016;120(1):26-34. https://doi.org/10.101 6/j.healthpol.2015.10.004

12. Baird K. High out-of-pocket medical spending among the poor and elderly in nine developed countries. Health Serv Res. 2016;51(4):1467-88. https:// doi.org/10.1111/1475-6773.12444.

13. Palladino R, Lee JT, Hone T, Filippidis FT, Millett C. The great recession and increased cost sharing in European health systems. Health Aff. 2016;35(7): 1204-13. https://doi.org/10.1377/hlthaff.2015.1170.

14. Schokkaert E, Van Ourti T, De Graeve D, Lecluyse A, Van de Voorde C. Supplemental health insurance and equity of access in Belgium. Health Econ. 2010;19(4):377-95. https://doi.org/10.1002/hec.1478.

15. Tur-Sinai A, Litwin $\mathrm{H}$. Forgone visits to the doctor due to cost or lengthy waiting time among older adults in Europe. In: Börsch-Supan A, Kneip T, Litwin H, Myck M, Weber G, editors. Ageing in Europe - supporting policies for an inclusive society. Berlin: De Gruyter; 2015. p. 291-300.

16. Valtorta NK, Hanratty B. Socioeconomic variation in the financial consequences of ill health for older people with chronic diseases: a systematic review. Maturitas. 2013;74(4):313-33. https://doi.org/10.1016/j.ma turitas.2013.01.015

17. Crystal S, Johnson RW, Harman J, Sambamoorthi U, Kumar R. Out-of-pocket health care costs among older Americans. J Gerontol. 2000;55B:S51-62.

18. Wei W, Akincigil A, Crystal S, Sambamoorthi U. Gender differences in out-ofpocket prescription drug expenditures among the elderly. Res Aging. 2006; 28(4):427-53. https://doi.org/10.1177/0164027505284046.

19. Islam MM, Yen L, Valderas JM, McRae IS. Out-of-pocket expenditure by Australian seniors with chronic disease: the effect of specific diseases and morbidity clusters. BMC Public Health. 2014;14(1):1008. https://doi.org/10.11 86/1471-2458-14-1008

20. Alexa J, Rečka L, Votápková J, Van Ginneken E, Spranger A, Wittenbecher F. Czech Republic: health system review. Health Syst Transit. 2015;17(1):1-165.

21. Busse R, Blümel M. Germany: health system review. Health Syst Transit. 2014; 16(2):1-296

22. De Graeve D, Van Mechelen N, Vandelannoote D, De Wilde M. Measuring health care expenditures in Belgium: the at-risk-household approach. Flemosi Discussion Paper. 2013;23:1-43.

23. World Health Organization (WHO). Global Health Expenditure Database NHA indicators. Geneva: Who; 2020. http://apps.who.int/nha/database/ ViewData/Indicators/en. Accessed 7 Feb 2020.

24. Christelijke Mutualiteit (CM). Twaalfde CM-ziekenhuisbarometer. Brussel: CM; 2016. p. 1-51.

25. German Federal Ministry of Health (BMG) (2017) Zuzahlungsregelungen der gesetzlichen Krankenversicherung. Berlin; 2017. https://www. bundesgesundheitsministerium.de/fileadmin/Dateien/3_Downloads/A/A rzneimittelversorgung/Zuzahlungsregelungen_der_GKV.pdf. Accessed 20 Feb 2020

26. Börsch-Supan A. Survey of Health, Ageing and Retirement in Europe (SHAR E) Wave 6, Release version: 6.0.0. SHARE-ERIC data set. 2017. https://doi. org/10.6103/SHARE.w6.600

27. Börsch-Supan A, Brandt M, Hunkler C, Kneip T, Korbmacher J, Malter F, Schaan B, Stuck S, Zuber S. Data resource profile: the survey of health, ageing and retirement in Europe (SHARE). Int J Epidemiol. 2013;42(4):9921001. https://doi.org/10.1093/ije/dyt088.

28. Malter F, Börsch-Supan A. SHARE Wave 6: Panel innovations and collecting Dried Blood Spots. Munich: Munich Center for the Economics of Aging (MEA); 2017

29. Murray CJL, Knaul F, Musgrove P, Xu K, Kawabata K. Defining and measuring fairness in financial contribution to the health system. GPE Discussion Paper Series. 2000;24.

30. Xu K, Klavus J, Kawabata K, Evans DB, Hanvoravongchai P, Ortiz JP, Zeramdini R, Murray CJ. Household health system contributions and capacity to pay: definitional, empirical and technical challenges. In: Murray CIL, Evans DB, editors. Health systems performance assessment: debates, methods and empiricism. Geneva: WHO; 2003. p. 533-42.
31. Bock JO, Matschinger H, Brenner H, Wild B, Haefeli WE, Quinzler R, Saum KU, Heider D, König HH. Inequalities in out-of-pocket payments for health care services among elderly Germans - results of a population-based crosssectional study. Int J Equity Health. 2014;13(1):3. https://doi.org/10.1186/14 75-9276-13-3.

32. Bremer P. Forgone care and financial burden due to out-of-pocket payments within the German health care system. Health Econ Rev. 2014; 4(1):36. https://doi.org/10.1186/s13561-014-0036-0.

33. OECD. OECD framework for statistics on the distribution of household income, consumption and wealth. Paris: OECD Publishing; 2013. https://doi. org/10.1787/9789264194830-en.

34. Andersen R, Newman JF. Societal and individual determinants of medical care utilization in the United States. Milbank Q. 2005;83:1-28.

35. Özgen Narcı H, Şahin I, Yıldırım HH. Financial catastrophe and poverty impacts of out-of-pocket health payments in Turkey. Eur J Health Econ. 2015;16(3):255-70. https://doi.org/10.1007/s10198-014-0570-z.

36. Bernell S, Howard SW. Use your words carefully: what is a chronic disease? Front Public Health. 2016;4:159.

37. Jones AM. Health Econometrics. In: Cuyler AJ, Newhouse JP, editors. Handbook of Health Economics, Volume 1A. North Holland; 2000. p. 265-344.

38. Mihaylova B, Briggs A, O'Hagan A, Thompson SG. Review of statistical methods for Analysing healthcare resources and costs. Health Econ. 2011; 20(8):897-916. https://doi.org/10.1002/hec.1653.

39. Buntin MB, Zaslavsky AM. Too much ado about two-part models and transformation? Comparing methods of modeling Medicare expenditures. J Health Econ. 2004;23(3):525-42. https://doi.org/10.1016/j.jhealeco.2003.10.005.

40. Cantoni $E$, Ronchetti E. A robust approach for skewed and heavy-tailed outcomes in the analysis of health care expenditures. J Health Econ. 2006; 25(2):198-213. https://doi.org/10.1016/j.jhealeco.2005.04.010.

41. Mullahy J. Much ado about two: reconsidering retransformation and the two-part model in health econometrics. J Health Econ. 1998;17(3):247-81. https://doi.org/10.1016/S0167-6296(98)00030-7.

42. Duan N, Manning WG, Morris CN, Newhouse JP. A comparison of alternative models for the demand for medical care. J Bus Econ Stat. 1983;1:115-26.

43. Norton EC, Dow WH, Do YK. Specification tests for the sample selection and two-part models. Health Serv Outcome Res Methodol. 2008;8(4):201-8. https://doi.org/10.1007/s10742-008-0037-8.

44. Penders YWH, Rietjens J, Albers G, Croezen S, Van den Block L. Differences in out-of-pocket costs of healthcare in the last year of life of older people in 13 European countries. Palliat Med. 2017;31(1):42-52. https://doi.org/10.11 77/0269216316647206

45. Holly A, Lamiraud K, Moschetti K, Yalcin T. Changes in Health Out-of-Pocket Payments and Health Care Utilization in the Early Post-Retirement Period. In: Börsch-Supan A, Brugiavini A, Jürges H, Kapteyn A, Mackenbach J, Siegrist J, Weber $G$, editors. First results from the Survey of Health, Ageing and Retirement in Europe (2004-2007): Starting the longitudinal dimension. Mannheim: Mannheim Research Institute for the Economics of Aging (MEA); 2008;156-62.

46. Prevolnik Rupel V, Hren R, Srakar A. Analiza izdatkov iz žepa za zdravstvo: rezultati na podlagi 4. vala raziskave SHARE (Analysis of out-of-pocket expenses for health care: results of the fourth wave of the SHARE survey). In: Majcen B, editor. Značilnosti starejšega prebivalstva $\vee$ Sloveniji - prvi rezultati. Ljubljana: Institute for Economic Research (IER); 2015; 83-93.

47. Krůtilová V. Access to health care and the out-of-pocket burden of the European elderly. Acta Univ Agric Silvic Mendelianae Brun. 2016;64:1961-70.

48. Bouckaert N, Maertens de Noordhout C, Van de Voorde C. Health System Performance Assessment: how equitable is the Belgian health system? Health Services Research (HSR). Brussels: Belgian Health Care Knowledge Centre (KCE); 2020. p. 1-99.

49. Czech Statistical Office (CZSO). Expenditures and Consumption of Households Included in the Household Budget Survey in 2015. CZSO; 2017. https://www.czso.cz/csu/czso/expenditures-and-consumption-ofhouseholds-included-in-the-household-budget-survey-households-by-a ctivity-status-of-the-head-of-household-by-municipality-size-income-bra ckets-cohesion-regions-2015. Accessed 7 Feb 2021.

\section{Publisher's Note}

Springer Nature remains neutral with regard to jurisdictional claims in published maps and institutional affiliations. 